\title{
Slow Growth and Sluggish Manufacturing in Indonesiae"s Less Competitive Provinces: A Geweke Causality Analysis
}

\author{
Tan Khee Giap ${ }^{1} \&$ Mulya Amri ${ }^{2}$ \\ ${ }^{1}$ Tan Khee Giap, Co-director, Asia Competitiveness Institute, Lee Kuan Yew School of Public Policy, National \\ University of Singapore, Singapore \\ ${ }^{2}$ Mulya Amri, Research Fellow, Asia Competitiveness Institute, Lee Kuan Yew School of Public Policy, National \\ University of Singapore, Singapore
}

Correspondence: Tan Khee Giap, Co-Director at the Asia Competitiveness Institute and Associate Professor, Lee Kuan Yew School of Public Policy, National University of Singapore, Singapore. E-mail: spptkg@nus.edu.sg

Received: January 12, 2018

doi:10.11114/afa.v4i2.3093
Accepted: March 6, $2018 \quad$ Available online: March 11, 2018

URL: https://doi.org/10.11114/afa.v4i2.3093

\begin{abstract}
This article presents a causality analysis of lagging economic growth in two Indonesian provinces: East Nusa Tenggara and North Maluku. We identify three variables which stand out for some of Indonesiae s economically challenged provinces: consistently low gross domestic product (GDP) growth, low levels of manufacturing, and under-utilisation of labour. Using Geweke causality analysis, we identify and measure the direction of causal effects between these variables. Our empirical findings confirm that output growth is affected by the level of value addition in economic activities and the productivity of human resources. We find that both the secondary sector ${ }^{\text {ee }}$ s contribution to gross regional development product (GRDP) and labour productivity contribute to the changes in overall provincial GRDP, but not the other way around. Such findings suggest that development in Indonesia ${ }^{\text {ee }}$ economically challenged provinces would benefit greatly from expansion of appropriate manufacturing and value added activities, and more productive utilization of labour force in full employment situations.
\end{abstract}

Keywords: Geweke causality, economic growth, manufacturing, labour productivity, competitiveness, East Nusa Tenggara, North Maluku, Indonesia

\section{Introduction}

Economic development takes place unevenly across sub-national entities. Output growth in an economy can be driven by the extent of manufacturing and other value-adding activities (for example, see Thirlwall, 1983; Timmer \& Szirmai, 2000; Cornwall, 1977), as well as the productivity of an economyes labour force ( Baily, Bartelsman, \& Haltiwanger, 1996; Chan, 1970; Katz, 2000). While a considerable number of studies using cross-section and panel data already exist, the related literature employing time-series data specifically to understand the growth patterns in lagging subnational regions of emerging market economies (EMEs) appears to be scarce.

In this context, Indonesia offers an interesting case study to explore such related issues empirically at the provincial level. The country is of tremendous size and diversity. It registered a healthy annual growth rate of $5.3 \%$ on average during the decade of the 2000s. Despite this progress, economic growth in several provinces have remained slow. In light of Indonesiaes current attempt to revive its slowing economy amidst the global downturn (Negara, 2015; Parlina, 2014; Rumbaugh, 2012; The Wall Street Journal, 2015), and considering the country's adoption of decentralization policies since 2001 (Ahmad \& Mansoor, 2002; Hill, 2014), it is important to understand the processes underlying economic development (or lack thereof) at the sub-national level.

The Asia Competitiveness Institute (ACI) $)^{e s}$ annual ranking of 33 Indonesian provinces ${ }^{1}$ consistently ranked East Nusa Tenggara and North Maluku among the least competitive (Tan \& Amri, 2013; Tan, Amri, Low, \& Tan, 2013; Tan,

\footnotetext{
${ }^{1}$ Indonesia ${ }^{\text {ee }} \mathrm{s} 34^{\text {th }}$ province (North Kalimantan) was approved in 2012, but disaggregated data for the new province has not been made available.
} 
Merdikawati, Amri, \& Berger, 2015). Similar studies also confirm some less than favourable aspects related to business and investment climate in the two provinces (Partnership for Governance Reform, 2013), as well as in the cities and regencies within them (KPPOD \& The Asia Foundation, 2007, 2011).

Given this background, in this article we will present a causality analysis of output growth in East Nusa Tenggara and North Maluku using a methodology developed by Geweke (1982) that identifies and measures the direction of causal effects between two or more variables. ${ }^{2}$ Findings of the Geweke causality analysis confirm general theories and past empirical works that argue that output growth is affected by the presence of value-adding activities and effective utilization of the labour force. These further emphasize the calls for Indonesia to expand its manufacturing sector and provide employment opportunities to its labour force, as well as improve labour productivity.

The rest of the paper is structured as follows: Section 2 presents an outline of the key socio-economic characteristics of East Nusa Tenggara and North Maluku, focusing on economic growth, manufacturing, and productivity aspects. These will provide the base for developing empirically testable hypotheses that we do so in the paper. Section 3 provides a description of the data and methodology used in the paper. Specifically, it furnishes the framework of Geweke causality analysis and the related empirical strategy. Empirical results are discussed in Section 4, while Section 5 concludes with a brief note on policy implications.

\section{Background and Hypotheses}

\subsection{East Nusa Tenggara}

East Nusa Tenggara is an archipelagic province located in the south-eastern part of Indonesia, bordering Timor Leste and Australia. Unlike in many other Indonesian areas, the East Nusa Tenggara Islands are relatively dryer with semi-arid climate. Savannah, instead of tropical rainforests, forms a substantial part of the province's mountainous landscape. East Nusa Tenggara has a population of 4.78 million people (based on 2011 data), which makes it the 12th most populous province in Indonesia. It also has the lowest rate of urbanisation in the country, where only $19.3 \%$ of the population lived in urban areas.

There are a number of challenges facing the province. First, East Nusa Tenggara is the poorest among Indonesia"s provinces, with the lowest GRDP per capita. In 2011, the province's GRDP per capita was 2,773,900 Rupiah in 2000 constant prices. At the same time, it is one of the provinces with the highest poverty rates in Indonesia, where about one-fifth $(20.5 \%)$ of the population lived under the poverty line.

East Nusa Tenggara's economic size is small compared to other provinces. For instance, the provincial GRDP in 2011 was 12,531 billion Rupiah while that of the average Indonesian province was 67,321 billion Rupiah in 2000 constant prices. This means that East Nusa Tenggara's GRDP was only about $18 \%$ of the national average. Within a ten year period, we see that East Nusa Tenggara's economy has grown by about $60 \%$ from 7,850 billion in 2000 to 12,531 billion Rupiah in 2010 . The average province, for comparison, has grown by $63 \%$, from 41,378 billion to 67,321 billion Rupiah.

East Nusa Tenggara "s economic structure is dominated by the primary and tertiary sectors. The former constitutes around 38\% of the GRDP in 2011 and is dominated by livestock products such as cows and buffalos, and plantation products such as cassava, sweet potato, and maize. With a coastline of 5,700 kilometres, there is also a substantial but underdeveloped potential for fishery. The tertiary sector constitutes 53\% of the GRDP in 2011. Most of this is generated by public service, retail trade, hotels, and restaurants. East Nusa Tenggara also has a large but underdeveloped tourism potential due to its scenic mountainous and rich marine biodiversity. The secondary sector constitutes a meagre $9 \%$ of the GRDP, and includes industries such as food and beverages, textile, furniture, and metal crafts. These are mostly micro- and small-sized cottage industries, operating with limited resources and capacity. Over the years, the manufacturing sector in East Nusa Tenggara has remained small with very slow growth (see Figure 1).

\footnotetext{
${ }^{2}$ Geweke (1982) expanded the methodology of causality analysis developed earlier by Granger (1969) and Sims (1972). See Appendix for a technical description of the methodology.
} 


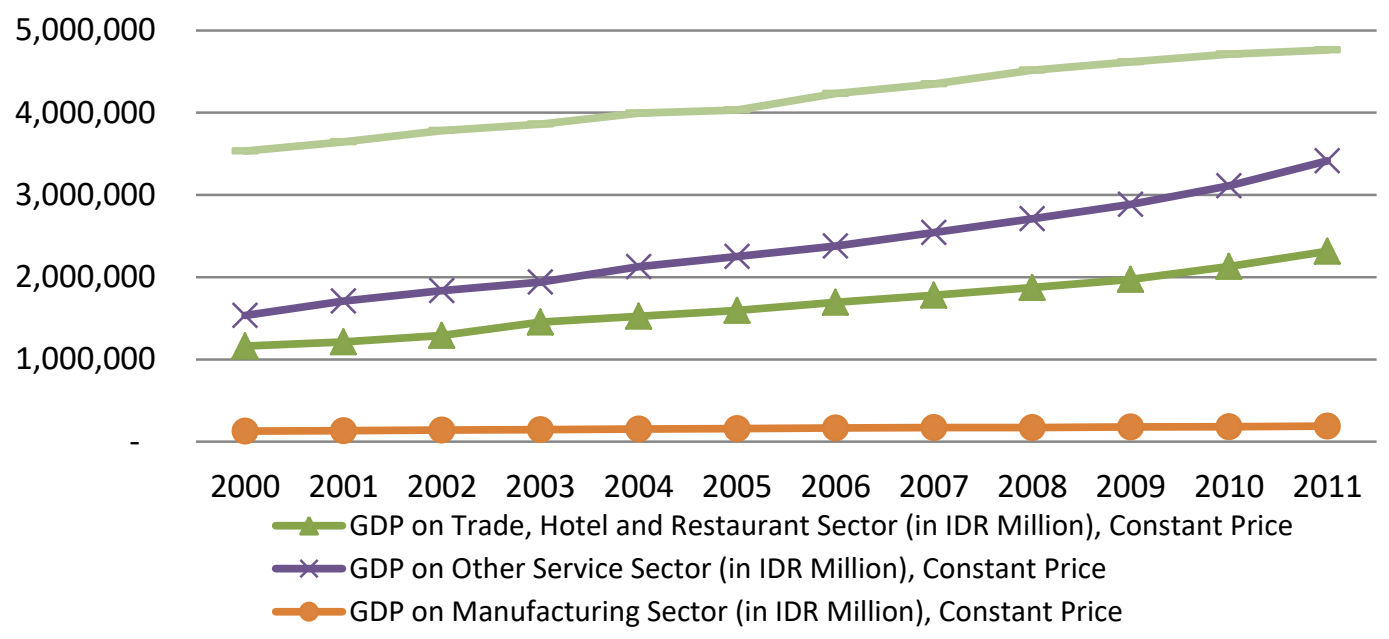

Figure 1. East Nusa Tenggara"s GRDP by Major Sectors (2000-2011)

Source: Asia Competitiveness Institute using data from World Bank INDO-DAPOER (Indonesia Database for Policy and Economic Research)

Labour relations present another problem for East Nusa Tenggara as ACI's annual competitiveness analysis found that the province is in the last place among the 33 provinces in terms of labour relations. Labour productivity is the lowest in the country, generating only 6.32 million Rupiah per worker per year in 2011. Unemployment rate was actually low at $2.7 \%$ in 2011 . However, if both unemployment and underemployment were taken into consideration, there was a large proportion of East Nusa Tenggara's labour force that was underemployed. In 2011, the combined rate of unemployment and underemployment was close to one half (49.2\%), signalling that one out of two persons did not have a regular job. Throughout the past decade, the province's combined unemployment and underemployment rate constantly hovered around $50 \%$, with a low of $47.3 \%$ in 2008 and a high of $60.7 \%$ in 2005 . Such situation is particularly troubling for graduates of secondary and tertiary education in the province, who are often forced to leave the province (Jones, Nagib, Sumono, \& Handayani, 1998).

\subsection{North Maluku}

North Maluku is an archipelagic province located in eastern Indonesia, between Papua Island and Sulawesi Island, just to the southeast of the Philippines. It used to be a part of a larger Maluku province, but North Maluku became a separate province in 1999. The Maluku Islands were once the world's primary source of nutmeg and mace spices during pre-colonial times. The islands of Ternate and Tidore, now part of the North Maluku, were once centres of influential archipelagic sultanates funded by spice trades. To this day, Indonesia remains the world's largest exporter of nutmeg, the bulk of which originates from the Maluku Islands.

North Maluku is characterised as a province with small number of population and size of the economy. Its population is the third smallest in Indonesia, with 1.06 million people in 2011. Meanwhile, the province"s GRDP in $2011(3,230$ billion Rupiah in 2000 constant prices) was the second lowest in the country, and is equivalent to $4.8 \%$ of the average province's GRDP. Low income is also another character of the province. With a figure of 3,038,400 Rupiah (2000 constant prices) in 2011, North Maluku's GRDP per capita was the fourth smallest among 33 Indonesian provinces.

North Maluku's economy is largely dependent on the primary sector and tertiary sectors. The former contributes to $41 \%$ of the GRDP in 2011, with notable products such as nutmeg, mace, clove, and fish. However, it should be noted that many parts of the province is characterised by subsistence economic activities (Latinis, 1999). The tertiary sector makes up about $42.5 \%$ of North Maluku's GRDP in 2011, and is dominated by activities related to public service, retail trade, and tourism. Indeed the province holds much potential for tourism destination, with numerous cultural and historical sites, as well as nature and marine resorts doting the province. The secondary sector (manufacturing) contributes to a meagre $16 \%$ of the GRDP and includes industries such as food and beverages, metal products, and furniture. The bulk of manufacturing activities in North Maluku are in the form of cottage industries that operate at small scale with small productivity. The trend seems to indicate that the tertiary sector may surpass the primary sector in a few years in terms of percentage contribution to GRDP. Meanwhile, growth of the manufacturing sector has been slow (see Figure 2). 


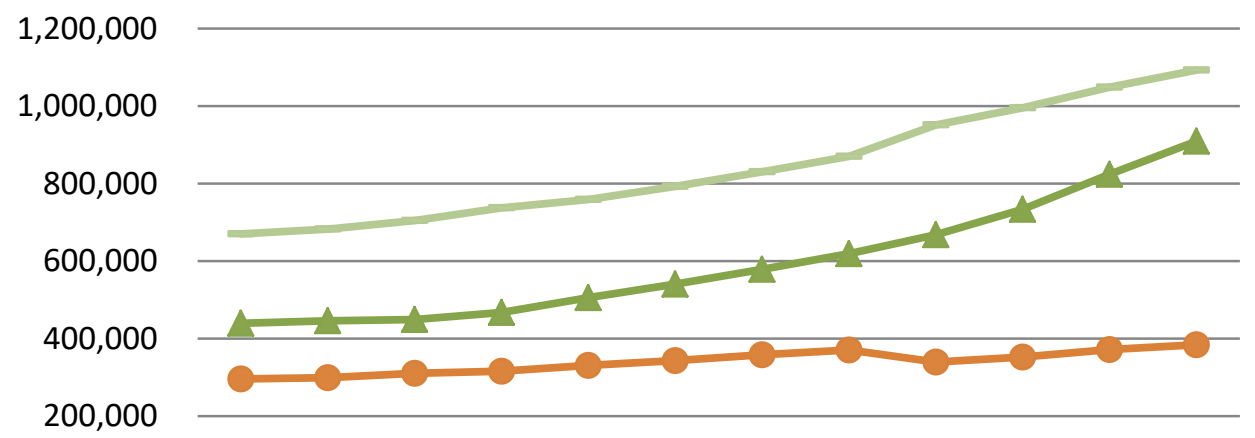

200020012002200320042005200620072008200920102011

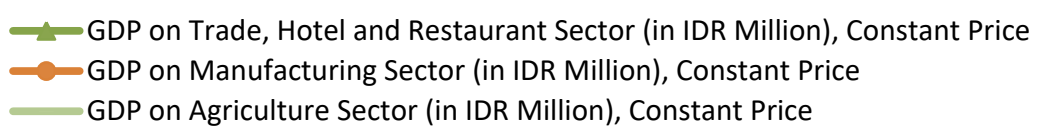

Figure 2. North Maluku's GRDP by Major Sectors (2000-2011)

Source: Asia Competitiveness Institute using data from World Bank INDO-DAPOER (Indonesia Database for Policy and Economic Research)

North Maluku faces major challenges in terms of productivity. It has the lowest tertiary sector productivity in the country (8.6 million Rupiah per worker per year) and the third lowest primary sector productivity (5.3 million Rupiah per worker per year). In terms of secondary sector productivity, North Maluku is doing slightly better at the 24th place out of 33 provinces (17.8 million Rupiah per worker per year), but this still places the province among the bottom-10 performers. Low productivity of the secondary sector is reflected in the small number of businesses in the fish processing business despite the relatively sizeable catch. Local firms are typically challenged in terms of resources and capacity. For example, with limited availability of cold storage, most of the catch is directly sold for exports with minimal or no processing.

\subsection{Hypothesis}

East Nusa Tenggara"s economic development trends show that the province"s GRDP remains small, with growth that is slower than that of the average province. Similarly, North Maluku's GRDP grows at a rate that is lower than that required to catch up. Further analysis of the sectoral breakdown in the provincial economy shows that both provinces have a weak manufacturing sector. While services is gradually taking over agriculture as a share of the provincial GRDP, manufacturing's role has been stagnant for extended periods. The contribution of manufacturing has remained about $9 \%$ of the GRDP for East Nusa Tenggara, and about $16 \%$ of the GRDP North Maluku, for over more than 10 years. The agriculture sector, which still plays an important role in both provinces"economy, remains largely subsistence in nature. Therefore, most agriculture products are not linked with value-added activities.

In North Maluku, although manufacturing plays a slightly more important role (compared to in East Nusa Tenggara), its productivity is not one to boast of. In terms of overall labour productivity, North Maluku is ranked 30th out of 33 provinces. The province's secondary sector productivity is not much better, ranked 24th out of 33 provinces. This represents a missed opportunity for the province to raise labour productivity and optimally utilise the labour force.

In East Nusa Tenggara, subsistent and low-productivity agriculture sector has proven to be insufficient to accommodate a growing population. Surplus labour from the agriculture sector cannot be absorbed by the local economy. Similar to the condition in North Maluku, this represents a missed opportunity for the province where a substantial portion of the labour force is underemployed and cannot contribute productively to the economy.

Several theories on sectoral shifts argue that an agricultural economy can grow faster by transforming into a manufacturing-oriented economy (Clark, 1957; Fisher, 1939). The argument goes that economies typically start as producers of primary products, and then as they develop, resources shift to the secondary sector, and ultimately to services (Rostow, 1960). As labour productivity in the primary sector is lower than that in the secondary sector, moving workers from agriculture to manufacturing activities leads to substantial and immediate boost in the economy 's overall productivity. This is the thinking behind the argument that manufacturing is ,the engine of growth (Thirlwall, 1983), which is then further developed as the "structural change bonus"eargument (Timmer \& Szirmai, 2000).

More thorough review of the arguments for industrialisation has been provided (for example, see Szirmai, 2012). 
Empirical data has shown the correlation between increasing level of manufacturing and rising income per capita in periods when developing countries were transitioning into developed ones (Bosworth, Collins, Chen, \& Brookings Institution, 1995; Chakravarty \& Mitra, 2009; Fagerberg \& Verspagen, 1999; Kaldor, 1967; Rodrik, 2009; Szirmai, 2012). Once a country achieves higher income levels compared to its agricultural era, its demand pattern will change and prefer to buy more manufactured goods and services compared to basic food products (Kuznets, 1966), triggering even further levels of industrialisation. The secondary sector promotes local growth also by triggering capital to accumulate in a concentrated rather than dispersed area, by providing better economies of scale, more opportunities for technological progress (Cornwall, 1977), better likelihood of learning and spillover effects, as well as more backward and forward linkages to other sectors and sub-sectors of the economy (Hirschman, 1958; Hla Myint, 1967).

East Nusa Tenggara and North Maluku have been largely agricultural (primary sector-based) provinces for a long time and it is now fitting to engage in more manufacturing activities to improve the economic growth. The manufacturing sector can absorb labour from the agriculture sector, creating higher value-added products that are labour-intensive, and thus, is more likely to create employment opportunities.

The above discussion seems to bind various key conditions of East Nusa Tenggara and North Maluku (economic growth levels, secondary sector's contributions to the GRDP, and utilisation and productivity of the labour force) into a hypothesis which we aim to empirically test in this paper. We hypothesise that the two provinces"low growth levels are contributed by the stagnant percentage change in the secondary sector"s contribution to the provincial economy, as well as by the low levels of full-time employment (for East Nusa Tenggara), and low levels of manufacturing labour productivity (for North Maluku). The remainder of the paper tests this formally and reports the results.

\section{Methodology and Data}

\subsection{Geweke Causality Analysis}

The methodology presented in this paper is consistent to that previously published in Tan, Nguyen and Ye (2015) and Tan, Gopalan and Ye (2016). Complementary tests for the existence of unidirectional causality have been provided by Granger (1969) and Sims (1972). Subsequently, Geweke (1982) developed the concept further by including instantaneous (two-way) linear feedback between multiple time series. Although the determinants of a single economic variable are likely to be multi-dimensional, most applications found in the literature focus on bi-variate cases.

The multi-variate causality test proposed by Geweke (1982) is essentially a test between two vectors of variables. The equivalence of linear dependence measures enables the conduction of a multivariate test which is as convenient as a bivariate test. Essentially, the idea of causality between multiple time series $\mathrm{X}$ and $\mathrm{Y}$ can be summarized as follows:

$$
F_{X, Y}=F_{X \rightarrow Y}+F_{Y \rightarrow X}+F_{X \cdot Y}
$$

This means the measure of linear dependence between two series of variables $\left(F_{X, Y}\right)$ is the sum of the measures of linear feedback from the first series to the second $\left(F_{X \rightarrow Y}\right)$, linear feedback from the second series to the first $\left(F_{Y \rightarrow X}\right)$, and instantaneous linear feedback between the two series $\left(F_{X \cdot Y}\right)$. The measures are non-negative and zero only when feedback (causality) of the relevant type is absent.

Like Granger (1969) and Sims (1972), Geweke's causality analysis focused the attention on a wide-sense stationary, purely non-deterministic multiple time series $Z=\left\{z_{t}, \mathrm{t}\right.$ real $\}$. Therefore, the vector $z_{t}$ can be expressed under the following autoregressive representation:

$$
z_{t}=\sum_{s=1}^{\infty} B_{s} z_{t-s}+e_{t}
$$

where $e_{t}$ is white noise and $z_{t}$ can be partitioned into $\mathrm{k} \times 1$ and $1 \times 1$ sub-vectors $x_{t}$ and $y_{t}$.

Geweke also showed that a canonical form for the wide-sense stationary time series $z_{t}=\left(x_{t}, y_{t}\right)$ is of the form:

$$
\begin{array}{cl}
x_{t}=\sum_{s=1}^{\infty} E_{1 s} x_{t-s}+u_{1 t} & \operatorname{var}\left(u_{1 t}\right)=\Sigma_{1} \\
x_{t}=\sum_{s=1}^{\infty} E_{2 s} x_{t-s}+\sum_{s=1}^{\infty} F_{2 s} y_{t-s}+u_{2 t} & \operatorname{var}\left(u_{2 t}\right)=\Sigma_{2} \\
x_{t}=\sum_{s=1}^{\infty} E_{3 s} x_{t-s}+\sum_{s=0}^{\infty} F_{3 s} y_{t-s}+u_{3 t} & \operatorname{var}\left(u_{3 t}\right)=\Sigma_{3} \\
x_{t}=\sum_{s=1}^{\infty} E_{4 s} x_{t-s}+\sum_{s=-\infty}^{\infty} F_{4 s} y_{t-s}+u_{4 t} & \operatorname{var}\left(u_{4 t}\right)=\Sigma_{4} \\
y_{t}=\sum_{s=1}^{\infty} G_{1 s} y_{t-s}+v_{1 t} & \operatorname{var}\left(v_{1 t}\right)=\mathrm{T}_{1} \\
y_{t}=\sum_{s=1}^{\infty} G_{2 s} y_{t-s}+\sum_{s=1}^{\infty} H_{2 s} x_{t-s}+v_{2 t} & \operatorname{var}\left(v_{2 t}\right)=\mathrm{T}_{2} \\
y_{t}=\sum_{s=1}^{\infty} G_{3 s} y_{t-s}+\sum_{s=0}^{\infty} H_{3 s} x_{t-s}+v_{3 t} & \operatorname{var}\left(v_{3 t}\right)=\mathrm{T}_{3} \\
y_{t}=\sum_{s=1}^{\infty} G_{4 s} y_{t-s}+\sum_{s=-\infty}^{\infty} H_{4 s} x_{t-s}+v_{4 t} & \operatorname{var}\left(v_{4 t}\right)=\mathrm{T}_{4}
\end{array}
$$


The measure of linear feedback from $\mathrm{Y}$ to $\mathrm{X}$ is defined as:

$$
F_{Y \rightarrow X}=\ln \left(\left|\Sigma_{1}\right| /\left|\Sigma_{2}\right|\right)
$$

The measure $F_{Y \rightarrow X}$ is always non-negative and takes the value of zero only if the linear feedback running from $\mathrm{Y}$ to $\mathrm{X}$ is absent. Symmetrically, the measure of linear feedback from $\mathrm{X}$ to $\mathrm{Y}$ is defined as:

$$
F_{X \rightarrow Y}=\ln \left(\left|\mathrm{T}_{1}\right| /\left|\mathrm{T}_{2}\right|\right)
$$

The instantaneous feedback is defined as:

$$
F_{X \cdot Y}=\ln \left(\left|\mathrm{T}_{2}\right| \times\left|\Sigma_{2}\right| /|Y|\right)
$$

where,

$\Upsilon=\operatorname{var}\left(\begin{array}{c}u_{2 t} \\ v_{2 t}\end{array}\right)=\left[\begin{array}{cc}\Sigma_{2} & C \\ C^{\prime} & T_{2}\end{array}\right]$

Thus, the measure of linear feedback between two vectors $\mathrm{X}$ and $\mathrm{Y}$ can be decomposed into the sum of measure of linear feedback from $\mathrm{X}$ to $\mathrm{Y}$, the measure of linear feedback from $\mathrm{Y}$ to $\mathrm{X}$, and the instantaneous linear feedback between the two vectors. That is:

$$
F_{X, Y}=F_{X \rightarrow Y}+F_{Y \rightarrow X}+F_{X \cdot Y}
$$

It is useful to note that the absence of a particular causal ordering implies that one of these feedback measures is equal to zero.

Geweke also proved that the equations in the following set are equivalent:

$$
\begin{gathered}
F_{X, Y}=\ln \left(\left|\Sigma_{1}\right| \times\left|\mathrm{T}_{1}\right| /|Y|\right)=\ln \left(\left|\Sigma_{1}\right| /\left|\Sigma_{4}\right|\right)=\ln \left(\left|\mathrm{T}_{1}\right| /\left|\mathrm{T}_{4}\right|\right. \\
F_{X \rightarrow Y}=\ln \left(\left|\mathrm{T}_{1}\right| /\left|\mathrm{T}_{2}\right|\right)=\ln \left(\left|\Sigma_{3}\right| /\left|\Sigma_{4}\right|\right) \\
F_{Y \rightarrow X}=\ln \left(\left|\Sigma_{1}\right| /\left|\Sigma_{2}\right|\right)=\ln \left(\left|\mathrm{T}_{3}\right| /\left|\mathrm{T}_{4}\right|\right) \\
F_{X \cdot Y}=\ln \left(\left|\mathrm{T}_{2}\right| \times\left|\Sigma_{2}\right| /|Y|\right)=\ln \left(\left|\Sigma_{2}\right| /\left|\Sigma_{3}\right|\right)=\ln \left(\left|\mathrm{T}_{2}\right| /\left|\mathrm{T}_{3}\right|\right)
\end{gathered}
$$

The distribution of statistics and the calculation of their respective confidence intervals can be found in the Appendix.

\subsection{Data Description}

The dependent variable selected for the Geweke causality analysis of both East Nusa Tenggara and North Maluku is the change in overall Gross Regional Domestic Product (GRDP), as measured in 2000 constant prices. This variable is chosen to represent the growth of the provincial economy. Here, the change $(\Delta)$ is derived from first order difference.

Of the two independent variables, one is related to the dynamics in the province's economic structure, namely the change in percentage contribution of the secondary or manufacturing sector to the overall provincial GRDP (SECSEC). Again, here the change $(\Delta)$ is derived from first order difference.

The other independent variable is related to the utilisation of the labour force in the provincial economy. Here we use slightly different indicators for East Nusa Tenggara and North Maluku. For East Nusa Tenggara, we use the actual total number of unemployed and underemployed labour force in the province (UNDEMP), which represents the missed opportunity of underutilised workers. As for North Maluku, we use productivity of the secondary or manufacturing sector, defined as GRDP derived from the manufacturing sector divided by the total number of workers in said sector, measured in 2000 constant prices (PROMAN). For all four variables, the data is sourced from the Indo-Dapoer database maintained by the World Bank. ${ }^{3}$ For a summary of the variables and notations used in this paper, see Table 1.

Table 1. Summary of Variables and Notations Used in this Paper

\begin{tabular}{lll}
\hline Variable & Notation & Definition \\
\hline $\mathrm{X}$ & GRDP & $\Delta$ GRDP \\
\hline Y1 & SECSEC & $\Delta$ Percentage of Secondary Sector in GRDP \\
\hline $\begin{array}{l}\text { Y2 } \\
\text { (for East Nusa Tenggara) }\end{array}$ & UNDEMP & $\begin{array}{l}\text { Total Number of Unemployed and Underemployed } \\
\text { Labour Force }\end{array}$ \\
\hline $\begin{array}{l}\text { Y2 } \\
\text { (for North Maluku) }\end{array}$ & PROMAN & Productivity of the Manufacturing Sector \\
\hline
\end{tabular}

Source: Authors

To conduct the Geweke Analysis, a time-series data with at least 30 data points is needed for each indicator.

\footnotetext{
${ }^{3}$ Indo-Dapoer stands for Indonesia Database for Policy and Economic Research. It can be accessed online through: http://data.worldbank.org/data-catalog/indonesia-database-for-policy-and-economic-research. Data used in this research was accessed in September of 2014.
} 
Considering two important issues, (1) limited availability of data at the province level that goes back 30 years, and (2) the presence of several structural breaks in Indonesia"s political economic history, we used quarterly (instead of yearly) data, for a period of 11 years (2000 until 2011). This provides us with 44 data points (quarters) for each indicator.

Since the data was only available on a yearly basis (11 data points for each indicator), we converted the yearly data into quarterly data. The method of conversion from yearly to quarterly data was (1) "Quadratic Match Sum" for the change in GRDP, (2) "Quadratic Match Average" for change in the contribution of the secondary sector to GRDP, (3) "Quadratic Match Average" for the total number of unemployed and underemployed labour force in East Nusa Tenggara, and (4) "Quadratic Match Sum" for manufacturing sector productivity in North Maluku. All variables used in empirical estimations were subjected to statistical checks and stationarity tests.

In terms of the structural breakdown of GRDP, the data shows that East Nusa Tenggara's economic structure between 2000 and 2011 has changed to some extent with a steady increase in the proportion of the tertiary sector in the GRDP, and a steady decline in the proportion of the primary sector. The secondary sector (SECSEC), however, remained stagnant in terms of percentage contribution to GRDP. In the first quarter of 2000, manufacturing contributed to about $10.1 \%$ of East Nusa Tenggara"s GRDP. In the fourth quarter of 2011, however, its contribution has declined slightly to $8.9 \%$.

As for North Maluku, the data shows a similarity in terms of how the proportion of secondary sector in the provincial GRDP has remained unchanged between 2000 and 2011. Each of the primary and tertiary sectors still formed around $40 \%-42 \%$ of the provincees GRDP in 2011, comparable to their contributions in 2000. Meanwhile, manufacturing activities or the secondary sector still made up around $16 \%-17 \%$ of North Maluku's GRDP in 2011, similar to the proportion in 2000.

In terms of labour force utilisation, the data shows that the total number of unemployed and underemployed labour force in East Nusa Tenggara (UNDEMP) has fluctuated over a period of 11 years. For example, there were more unemployed and underemployed people in 2005 and 2009 compared to other years, reaching a peak of around 1.2 million people in 2005 and a low of 907,000 people in 2001 . However, across the 11 years period there is an overall growing trend in the number of underutilised labour force in East Nusa Tenggara ${ }^{\circ}$ s economy.

Meanwhile, for North Maluku it can be noted that there was an increase in manufacturing sector productivity (PROMAN) from the first quarter of 2000 to the fourth quarter of 2011. Although manufacturing productivity had fluctuated, output per worker rose from 4.02 million to 8.74 million Rupiah between 2000 and 2011, in 2000 constant price. This is an increase in productivity of about $117 \%$ in over 11 years, which is quite substantial. However, considering that North Maluku was ranked 24th out of 33 provinces in manufacturing sector productivity in 2011, further improvements are needed to catch up with other parts of Indonesia.

\section{Empirical Results}

\subsection{East Nusa Tenggara}

The Geweke analysis is conducted in both bi-variate and multi-variate approaches. In the bi-variate analysis, correlation between the dependent variable (X) and independent variables ( $\mathrm{Y} 1$ and $\mathrm{Y} 2)$ were tested separately. This means that Geweke tests were conducted between $\mathrm{X}$ and $\mathrm{Y} 1$ as well as between $\mathrm{X}$ and $\mathrm{Y} 2$, checking the extent of correlation in both directions ( $\mathrm{X}$ to $\mathrm{Y}$ and $\mathrm{Y}$ to $\mathrm{X}$ ).

Through the bi-variate analysis, first we discuss the correlation between the change in economic output (GRDP) and contribution of the secondary sector in the provincial economy (SECSEC) of East Nusa Tenggara.

Table 2 shows a significant total correlation between GRDP and SECSEC in either direction $\left(F_{x, y}\right.$ is significant at $1 \%$ level for both directions). Most of the correlation takes place instantaneously between GRDP and SECSEC ( $F_{x \cdot y}$ is significant at $1 \%$ level for both directions). When looking at each direction, we find there were no significant correlation for both $F_{x \rightarrow y}$ and $F_{y \rightarrow x}$ when SECSEC was considered as X and GRDP was considered as $\mathrm{Y}$ (second row). However, we do find a notable correlation (up to $1 \%$ level of significance) for $F_{y \rightarrow x}$ when GRDP was considered as X and SECSEC as Y (first row). These suggest that GRDP and SECSEC are significantly correlated, with most of the correlation taking place instantaneously between the two variables. However, there is also a possibility that a causal mechanism is taking place from SECSEC towards GRDP. 
Table 2. Estimated measures of bi-directional feedback Change of Economic Output (GRDP), Percentage of Secondary Sector in GRDP (SECSEC), and Number of Unemployed and Underemployed Labour Force (UNDEMP) for East Nusa Tenggara, Indonesia, 2000-2011

\begin{tabular}{|c|c|c|c|c|c|}
\hline \multicolumn{2}{|c|}{ Economic aggregates } & \multicolumn{4}{|c|}{$H_{0}\left(F_{x, y}=F_{x \rightarrow y}+F_{y \rightarrow x}+F_{x \cdot y}\right)$} \\
\hline$x$ & $y$ & $F_{x, v}$ & $F_{x \rightarrow v}$ & $F_{\nu \rightarrow x}$ & $F_{x \cdot v}$ \\
\hline \multirow{3}{*}{ GRDP } & \multirow{3}{*}{ SECSEC } & $1.5640 * * *$ & 0.0122 & $0.2073 * * *$ & $1.3445^{* * *}$ \\
\hline & & $(0.0000)$ & $(0.4592)$ & $(0.0023)$ & $(0.0000)$ \\
\hline & & $1.3606 * * *$ & 0.0094 & 0.0068 & $1.3445 * * *$ \\
\hline \multirow[t]{2}{*}{ SECSEC } & \multirow[t]{2}{*}{ GRDP } & $(0.0000)$ & $(0.5158)$ & $(0.5813)$ & $(0.0000)$ \\
\hline & & $1.4365 * * *$ & 0.1038 & $0.2048 * *$ & $1.1278 * * *$ \\
\hline \multirow{2}{*}{ GRDP } & \multirow{2}{*}{ UNDEMP } & $(0.0000)$ & $(0.1073)$ & $(0.0122)$ & $(0.0000)$ \\
\hline & & $1.3257 * * *$ & $0.1893 * *$ & 0.0085 & $1.1278 * * *$ \\
\hline UNDEMP & GRDP & $(0.0000)$ & $(0.0171)$ & $(0.8325)$ & $(0.0000)$ \\
\hline
\end{tabular}

a $*, * *$ and $* * *$ denote $10 \%, 5 \%$ and $1 \%$ level of significance, respectively.

Source: Authors

Next, we discuss the correlation between the change in GRDP and the total number of unemployed and underemployed persons in the province (UNDEMP). As also shown in

Table 2, we find a significant total correlation between GRDP and UNDEMP in either direction $\left(F_{x, y}\right.$ is significant at $1 \%$ level for both directions). Most of the correlation takes place instantaneously between GRDP and UNDEMP $\left(F_{x \cdot y}\right.$ is significant at $1 \%$ level for both directions). Looking at each direction, we find no significant correlation for $F_{x \rightarrow y}$ when GRDP was considered as $\mathrm{X}$ and UNDEMP was considered as $\mathrm{Y}$. We also find no significant correlation for $F_{y \rightarrow x}$ when UNDEMP was considered as X and GRDP was considered as $\mathrm{Y}$. These seem to suggest that there is no or very small likelihood of causal mechanism going from GRDP to UNDEMP. We do, however, found a significant correlation (up to $5 \%$ level of significance) for $F_{y \rightarrow x}$ when GRDP was considered as X and UNDEMP as Y. A similarly significant correlation (up to $5 \%$ level of significance) was also found for $F_{x \rightarrow y}$ when UNDEMP was considered as X and GRDP was considered as Y. These seem to suggest that there is a possibility of causal mechanism going from UNDEMP to GRDP.

In the multi-variate analysis, both the independent variables (Y1 and Y2, or EMP and ELEC) are aggregated (as Y) and its correlation with the dependent variable (X, or GDP) is tested. The multi-variate results are presented in Table 3. Table 3 shows that when SECSEC and UNDEMP were combined, we find a significant total correlation between $\mathrm{X}$ (GRDP) and Y (aggregate of SECSEC and UNDEMP) at the 1\% level of significance. Most or $84 \%$ of that association (1.9812 over 2.3500) takes place instantaneously. We also found a significant correlation at the $5 \%$ level of significance which takes place from $\mathrm{Y}$ going towards $\mathrm{X}$ that accounts for about $10 \%(0.2446$ over 2.3500$)$ of the total correlation. The correlation going from $\mathrm{X}$ towards $\mathrm{Y}$ is not significant.

Table 3. Estimated measures of multi-directional feedback between Change of Economic Output (GRDP), Percentage of Secondary Sector in GRDP (SECSEC), and Number of Unemployed and Underemployed Labour Force (UNDEMP) for East Nusa Tenggara, Indonesia, 2000-2011

\begin{tabular}{c|c|cccc}
\hline \multicolumn{2}{c|}{ Economic aggregates } & \multicolumn{4}{c}{$\boldsymbol{H}_{\mathbf{0}}\left(\boldsymbol{F}_{\boldsymbol{x} \boldsymbol{y}}=\boldsymbol{F}_{\boldsymbol{x} \rightarrow \boldsymbol{y}}+\boldsymbol{F}_{\boldsymbol{y} \rightarrow \boldsymbol{x}}+\boldsymbol{F}_{\boldsymbol{x} \cdot \boldsymbol{y}}\right)$} \\
\hline \multirow{4}{*}{$\boldsymbol{x}$} & $y$ & $F_{x, y}$ & $F_{x \rightarrow y}$ & $F_{y \rightarrow x}$ & $F_{x \cdot y}$ \\
\hline \multirow{3}{*}{ GRDP } & SECSEC & $2.3500 * * *$ & 0.1242 & $0.2446^{* *}$ & $1.9812^{* * * *}$ \\
\cline { 2 - 2 } & UNDEMP & $(0.0000)$ & $(0.2543)$ & $(0.0326)$ & $(0.0000)$ \\
\hline
\end{tabular}

a $*$, $*$ and $* * *$ denote $10 \%, 5 \%$ and $1 \%$ level of significance, respectively.

Source: Authors

These findings suggest in the case of East Nusa Tenggara, both the secondary sector's contribution to GRDP and size of unemployment and underemployment contribute to the change in overall provincial GRDP, but not the other way around. While instantaneous correlation between the dependent and independent variables are found, we also found correlation going from the independent variables (SECSEC and UNDEMP) towards the dependent variable (GRDP). The direction of causality is not two-way, as we did not find a significant correlation going from the dependent variable towards the independent variables.

\subsection{North Maluku}

The Geweke causality analysis for North Maluku was also conducted in both bi-variate and multi-variate models, as for East Nusa Tenggara above. 
Consistent with the main variable of interest, first through the bi-variate analysis we discuss the correlation between the change in economic output (GRDP) and the contribution of the secondary sector in the provincial economy (SECSEC). Table 4 shows a significant total correlation between GRDP and SECSEC in either direction $\left(F_{x, y}\right.$ is significant at $5 \%$ level when GRDP was considered as X, and 10\% when SECSEC was considered as X). Most of the correlation takes place instantaneously between GRDP and SECSEC ( $F_{x \cdot y}$ is significant at $5 \%$ level for both directions). When looking at each direction, we find a notable correlation (up to $5 \%$ level of significance) for $F_{y \rightarrow x}$ when GRDP was considered as $\mathrm{X}$ and SECSEC as $\mathrm{Y}$ (first row). However, there were no significant correlation for both $F_{x \rightarrow y}$ and $F_{y \rightarrow x}$ when SECSEC was considered as X and GRDP was considered as Y (second row). Similar to the results for East Nusa Tenggara, these suggest that GRDP and SECSEC are significantly correlated, with most of the correlation taking place instantaneously between the two variables. There is also a possibility that a causal mechanism is taking place from SECSEC towards GRDP.

Table 4. Estimated measures of bi-directional feedback Change of Economic Output (GRDP), Percentage of Secondary Sector in GRDP (SECSEC), and Productivity of Manufacturing Sector (PROMAN) for North Maluku, Indonesia, $2000-2011^{\text {a }}$

\begin{tabular}{|c|c|c|c|c|c|}
\hline \multicolumn{3}{|c|}{ Economic aggregates } & \multicolumn{3}{|c|}{$H_{0}\left(F_{x, y}=F_{x \rightarrow y}+F_{y \rightarrow x}+F_{x \cdot y}\right)$} \\
\hline$x$ & $y$ & $F_{x, y}$ & $F_{x \rightarrow y}$ & $F_{y \rightarrow x}$ & $F_{x \cdot \gamma}$ \\
\hline \multirow{3}{*}{ GRDP } & \multirow{3}{*}{ SECSEC } & $0.2258 * *$ & 0.0079 & $0.1076^{* *}$ & $0.1103^{* *}$ \\
\hline & & $(0.0173)$ & $(0.5522)$ & $(0.0278)$ & $(0.0259)$ \\
\hline & & $0.1491^{*}$ & 0.0356 & 0.0032 & $0.1103 * *$ \\
\hline \multirow[t]{2}{*}{ SECSEC } & \multirow[t]{2}{*}{ GRDP } & $(0.0817)$ & $(0.2053)$ & $(0.7045)$ & $(0.0259)$ \\
\hline & & $0.2175^{*}$ & 0.0209 & $0.1387^{*}$ & 0.0579 \\
\hline \multirow[t]{2}{*}{ GRDP } & \multirow[t]{2}{*}{ PROMAN } & $(0.0959)$ & (0.6378) & $(0.0507)$ & $(0.1147)$ \\
\hline & & $0.2727 * *$ & 0.1040 & $0.1108^{*}$ & 0.0579 \\
\hline PROMAN & GRDP & $(0.0388)$ & $(0.1069)$ & $(0.0923)$ & $(0.1147)$ \\
\hline
\end{tabular}

a $*$, $* *$ and $* * *$ denote $10 \%, 5 \%$ and $1 \%$ level of significance, respectively.

Source: Authors

Next, we discuss the correlation between the change in GRDP and the productivity of the manufacturing or secondary sector in the province (PROMAN). As also shown in Table 4, we find a significant total correlation between GRDP and PROMAN in either direction $\left(F_{x, y}\right.$ is significant at $5 \%$ level when PROMAN was considered as $\mathrm{X}$, and $10 \%$ when GRDP was considered as X). There is an ambiguous direction of the correlation, where we find a $10 \%$ level of significance for $F_{y \rightarrow x}$ when GRDP was considered as X (third row) and the same level of significance for $F_{y \rightarrow x}$ when PROMAN was considered as $\mathrm{X}$ (fourth row). Instantaneous correlation between GRDP and PROMAN $\left(F_{x \cdot y}\right)$ is not significant.

Results of the multi-variate analysis for North Maluku are presented in Table 5. Here we see that when SECSEC and PROMAN were combined, there is a significant total correlation between X (GRDP) and Y (aggregate of SECSEC and PROMAN) at the $5 \%$ level of significance. About one third or $33.9 \%$ of that association $(0.1518$ over 0.4474$)$ takes place instantaneously. We also found correlation at the $10 \%$ level of significance which takes place from $\mathrm{Y}$ going towards $\mathrm{X}$. The correlation going from $\mathrm{X}$ towards $\mathrm{Y}$, however, is not significant.

Table 5: Estimated measures of multi-directional feedback between Change of Economic Output (GRDP), Percentage of Secondary Sector in GRDP (SECSEC), and Productivity of Manufacturing Sector (PROMAN) for North Maluku, Indonesia, 2000-2011

\begin{tabular}{|c|c|c|c|c|c|}
\hline \multicolumn{2}{|c|}{ Economic aggregates } & \multicolumn{4}{|c|}{$H_{0}\left(F_{x, y}=F_{x \rightarrow y}+F_{y \rightarrow x}+F_{x \cdot y}\right)$} \\
\hline$x$ & $y$ & $F_{x, y}$ & $F_{x \rightarrow y}$ & $F_{y \rightarrow x}$ & $F_{x \cdot y}$ \\
\hline \multirow{2}{*}{ GRDP } & SECSEC & \multirow{2}{*}{$\begin{array}{c}0.4474 * * \\
(0.0373)\end{array}$} & \multirow{2}{*}{$\begin{array}{c}0.1074 \\
(0.3287)\end{array}$} & \multirow{2}{*}{$\begin{array}{l}0.1882 * \\
(0.0882)\end{array}$} & \multirow{2}{*}{$\begin{array}{c}0.1518 * * \\
(0.0382)\end{array}$} \\
\hline & PROMAN & & & & \\
\hline
\end{tabular}

$a *, * *$ and $* * *$ denote $10 \%, 5 \%$ and $1 \%$ level of significance, respectively.

Source: Authors

These findings suggest that for North Maluku, both the secondary sector's contribution to GRDP and the secondary sector"s labour productivity contribute to the change in overall provincial GRDP, but not the other way around. Instantaneous correlation between the dependent and independent variables are found, but we also found a notable correlation going from the independent variables (SECSEC and PROMAN) towards the dependent variable (GRDP). The direction of causality is likely not two-way, as we did not find correlation going from the dependent variable 
towards the independent variables. These results for North Maluku seem consistent with the findings for East Nusa Tenggara, albeit with a smaller level of significance.

\section{Conclusion and Policy Implications}

Indonesia is working to revive its growth level which has declined since 2014. Considering the uneven spread of economic activities, it is critical to better comprehend the possible causes of slow growth in the country"s less competitive regions. The call for more sub-national analyses is in-line with Indonesia"s decentralization policy (Hill, 2014) and its more recent drive to re-strengthen the role of province as coordinator of local economic development (USAID, 2009), as noted in Law No.12 of 2008 on sub-national governments.

For this purpose, Geweke causality analyses were conducted on two Indonesian provinces to understand better the underlying explanations for negligible economic growth over time. The cases of North Maluku and East Nusa Tenggara indicate that deficiency of growth is strongly associated with a stagnant manufacturing sector and low labour productivity over a period of 44 quarters. Both provinces used the same economic structure variable (which was the percentage of manufacturing sector contribution to GRDP). Both also used a productivity-related variable, which was productivity of the manufacturing sector for North Maluku and the number of unemployed and underemployed workers for East Nusa Tenggara.

The first variable highlights the importance of manufacturing as a labour-intensive sector that can drive higher productivity in an agricultural-based economy. In line with the theories of sectoral shift, moving away from subsistence farming and increasing value-adding activities through manufacturing is important to boost both province"s economy. Opportunities are abound to develop food processing industries based on the abundant plantation products in both provinces, as well as cattle in East Nusa Tenggara and fish in North Maluku. Infrastructure in the form of roads and ports, as well as a good business environment and local economic governance would help the rise of this sector.

East Nusa Tenggara's Geweke tests suggests that underutilisation of labour force is hampering the province's economic growth. We find that unemployment and underemployment may have led to lost opportunity for the province as well as the people. Therefore, the creation of full-time jobs is critical. Manufacturing provides opportunity to absorb a large number of labour force, but the workers need to be prepared, for example through vocational education and on-the-job trainings. In North Maluku we find the manufacturing sector is dominated by small cottage industries with low productivity. There is limited number of companies operating with substantial capital, and insufficient cold storage facilities, which is a critical issue for a maritime province. Much potential awaits to improve overall productivity through value-adding, but this requires substantial investment in infrastructure (e.g. roads, ports, and power), industrial facilities (e.g. cold storage), as well as labour force capacity (e.g. vocational skills).

Increasing manufacturing productivity does not mean neglecting agricultural productivity, which remains important for a large country like Indonesia (Tan, Merdikawati, Amri, \& Tan, 2015). Maluku and North Maluku have been identified in the national economic master plan (MP3EI) as the nation's primary fish source and reservoir, while East Nusa Tenggara has been designated as an important animal husbandry and fishery activity node (Coordinating Ministry for Economic Affairs, 2011). For provinces with large production potential in agriculture products, cattle, and fishery, the productivity of East Nusa Tenggara and North Maluku's manufacturing sector would benefit from the productivity of its primary sector. This is in-line with the argument that growth in agriculture is complementary to growth in manufacturing (de Souza, 2015) as low primary sector output leads to limited input for subsequent processing activities. Therefore, the strategy would be to improve the productivity of the secondary and primary sectors simultaneously. Increasing productivity can be achieved through upgrading local the Small and Medium Enterprises (SMEs) and attracting potential investors with higher capacity and more capital to partner with the SMEs and improve the latter's productivity and income (Blomstrom \& Sjoholm, 1999; Hamidi, 2014). Another way to boost industrialisation is to boost trade - both strategies has been shown to correlate with each other and with economic growth (Dodzin \& Vamvakidis, 2004; Park, 2011).

The objective of this research is to contribute to the literature on slow or lack of growth in the less competitive provinces of an emerging market economy, which has been found wanting. It also intends to add value to the more general literature through a time-series analysis on economic growth, industrialisation, and labour productivity. The analysis, however, faced some challenges in terms of quality and availability of data. Lack of sufficient data points originating from formal sources led to the interpolation of yearly data into quarterly data, which perhaps affected the quality of the analysis. Furthermore, focusing on a time series of a small number of variables may have created an omitted variable bias. Further research on the issues explored in this paper would benefit greatly from a more consistent and frequent tracking of the relevant data by officials. 


\section{References}

Ahmad, E., \& Mansoor, A. (2002). Indonesia: Managing Decentralization. In E. Ahmad \& V. Tanzi (Eds.), Managing fiscal decentralization. London: Routledge. https://doi.org/10.4324/9780203219997.ch14

Baily, M. N., Bartelsman, E. J., \& Haltiwanger, J. (1996). Labor productivity: structural change and cyclical dynamics. Cambridge, Mass: National Bureau of Economic Research. https://doi.org/10.3386/w5503

Blomstrom, M., \& Sjoholm, F. (1999). Technology transfer and spillovers: does local participation with multinationals matter? European Economic Review, 43(4-6), 915. https://doi.org/10.1016/S0014-2921(98)00104-4

Bosworth, B., Collins, S. M., Chen, Y., \& Brookings Institution. (1995). Accounting for differences in economic growth (Vol. no. 115.). Washington, D.D: Brookings Institution.

Chakravarty, S., \& Mitra, A. (2009). Is industry still the engine of growth? An econometric study of the organized sector employment in India. Journal of Policy Modeling, 31(1), 22-35. https://doi.org/10.1016/j.jpolmod.2008.06.002

Chan, W. Y. (1970). Labour productivity in manufacturing industries. Singapore: Economics Section, Economic Development Division, Ministry of Finance.

Clark, C. (1957). The conditions of economic progress (Vol. 3d). London: Macmillan.

Coordinating Ministry for Economic Affairs. (2011). Masterplan: Acceleration and Expansion of Indonesia Economic Development 2011-2025. Coordinating Ministry for Economic Affairs.

Cornwall, J. (1977). Modern capitalism: its growth and transformation. London: Martin Robertson.

de Souza, J. P. A. (2015). Evidence of growth complementarity between agriculture and industry in developing countries. Structural Change and Economic Dynamics, 34, 1-18. https://doi.org/10.1016/j.strueco.2015.05.001

Dodzin, S., \& Vamvakidis, A. (2004). Trade and industrialization in developing economies. Journal of Development Economics, 75(1), 319-328. https://doi.org/10.1016/j.jdeveco.2003.08.006

Fagerberg, J., \& Verspagen, B. (1999). Modern Capitalism in the 1970s and 1980s. In M. Setterfield (Ed.), Growth, Employment and Inflation. Houndmills, Basingstoke: MacMillan. https://doi.org/10.1007/978-1-349-27393-5_9

Fisher, A. G. B. (1939). Production, Primary, Secondary and Tertiary. Economic Record, 15(1), $24-38$. https://doi.org/10.1111/j.1475-4932.1939.tb01015.x

Geweke, J. (1982). Measurement of Linear Dependence and Feedback between Multiple Time Series. Journal of the American Statistical Association, 77(378), 304-313. https://doi.org/10.2307/2287238

Granger, C. W. J. (1969). Investigating Causal Relations by Econometric Models and Cross-Spectral Methods. Econometrica (Pre-1986), 37(3), 424. https://doi.org/10.2307/1912791

Hamidi, H. (2014). The Impact on Farm Profits of a Company's Partnership with a Potato Farm: The Case of the Partnership between PT. Indofood Fritolay Makmur and Potato Farmers in Sembalun District, in the Province of West Nusa Tenggara. Journal of Indonesian Economy and Business : JIEB, 29(2), 118.

Hill, H. (Ed.). (2014). Regional Dynamics in a Decentralized Indonesia. Singapore: Institute of Southeast Asian Studies.

Hirschman, A. O. (1958). The strategy of economic development (Vol. 10.). New Haven: Yale University Press.

Hla Myint, U. (1967). The economics of the developing countries (Vol. 3rd). London: Hutchinson.

Jones, G. W., Nagib, L., Sumono, \& Handayani, T. (1998). The Expansion of High School Education in Poor Regions: The Case of East Nusa Tenggara, Indonesia. Bulletin of Indonesian Economic Studies, 34(3), 59-84. https://doi.org/10.1080/00074919812331337420

Kaldor, N. (1967). Strategic factors in economic development (Vol. October 1966.). Ithaca: New York State School of Industrial and Labor Relations, Cornell University.

Katz, J. (2000). Structural Change and Labor Productivity Growth in Latin American Manufacturing Industries 1970-96. World Development, 28(9), 1583-1596. https://doi.org/10.1016/S0305-750X(00)00050-4

KPPOD, \& The Asia Foundation. (2011). Local Economic Governance: A Survey of Business Operators in 245 Districts/Municipalities in Indonesia, 2011. KPPOD, The Asia Foundation, and Australian Agency for International Development. Retrieved from http://asiafoundation.org/publications/pdf/1027

KPPOD, \& The Asia Foundation. (2007). Local Economic Governance: A Survey of Business Operators in 243 Districts/Municipalities in Indonesia, 2007. Jakarta, Indonesia: KPPOD, The Asia Foundation, supported by USAID.

Kuznets, S. S. (1966). Modern economic growth: rate, structure and spread (Vol. 7.). New Haven: Yale University Press. 
Latinis, D. K. (1999). Subsistence system diversification in southeast Asia and the Pacific: Where does Maluku fit? ProQuest Dissertations Publishing.

Negara, S. D. (2015). Jokowies infrastructure focus: is it Indonesia's new growth strategy? (Vol. 2015/18;2015/18.;). Singapore: Institute of Southeast Asian Studies.

Park, J. H. (2011). Trade-induced Industrialization and Economic Growth. International Economic Journal, 25(3), 513545. https://doi.org/10.1080/10168737.2011.607251

Parlina, I. (2014, December 24). Jokowi aims for 7 percent annual growth. The Jakarta Post. Retrieved from http://www.thejakartapost.com/news/2014/12/24/jokowi-aims-7-percent-annual-growth.html

Partnership for Governance Reform. (2013). Indonesia Governance Index 2012. Jakarta: Partnership for Governance Reform and Australian Agency for International Development.

Rodrik, D. (2009). Growth after the Crisis (SSRN Scholarly Paper No. ID 1507477). Rochester, NY: Social Science Research Network. Retrieved from https://papers.ssrn.com/abstract=1507477

Rostow, W. W. (1960). The process of economic growth (Vol. 2d). Oxford [Eng.]: Clarendon Press.

Rumbaugh, T. (2012). Indonesia: sustaining growth during global volatility (No. 1616352027;9781616352028;). Washington, D.C.: International Monetary Fund.

Sims, C. A. (1972). Money, Income, and Causality. The American Economic Review, 62(4), 540-552.

Szirmai, A. (2012). Industrialisation as an engine of growth in developing countries, 1950-2005. Structural Change and Economic Dynamics, 23(4), 406-420. https://doi.org/10.1016/j.strueco.2011.01.005

Tan, K. G., \& Amri, M. (2013). Subnational Competitiveness and National Performance: Analysis and Simulation for Indonesia. Journal of CENTRUM Cathedra: The Business and Economics Research Journal, 6(2), 173-192. https://doi.org/10.7835/jcc-berj-2013-0087

Tan, K. G., Amri, M., Low, L., \& Tan, K. Y. (2013). Competitiveness Analysis and Development Strategies for 33 Indonesian Provinces. World Scientific. https://doi.org/10.1142/8795

Tan, K. G., Gopalan, S., \& Ye, Y. (2016). Drivers of Growth in the Travel and Tourism Industry in Malaysia: A Geweke Causality Analysis. Economies, 4(1), 3. https://doi.org/10.3390/economies4010003

Tan, K. G., Merdikawati, N., Amri, M., \& Berger, B. H. (2015). 2014 Annual Competitiveness Analysis and Development Strategies for Indonesian Provinces. World Scientific. https://doi.org/10.1142/9822

Tan, K. G., Merdikawati, N., Amri, M., \& Tan, K. Y. (2015). 2014 Provincial and Inaugural Regional Competitiveness Analysis: Safeguarding Indonesia's Growth Momentum. World Scientific. https://doi.org/10.1142/9556

Tan, K. G., Nguyen, L. P. A., \& Ye, Y. D. (2015). Development Growth Models for Singapore and Malaysia: A Geweke Causality Analysis. Journal of Centrum Cathedra: The Business and Economics Research Journal, 8(2), 165-186. https://doi.org/10.1108/JCC-08-02-2015-B005

The Wall Street Journal. (2015, June 15). Indonesiaes Investment Aims - The Numbers. The Wall Street Journal. Retrieved from http://blogs.wsj.com/briefly/2015/06/15/indonesias-investment-aims-the-numbers/

Thirlwall, A. P. (1983). Growth and development: with special reference to developing economics (Vol. 3rd). London: Macmillan. https://doi.org/10.1007/978-1-349-06713-8

Timmer, M. P., \& Szirmai, A. (2000). Productivity growth in Asian manufacturing: the structural bonus hypothesis examined. Structural Change and Economic Dynamics, 11(4), 371-392. https://doi.org/10.1016/S0954-349X(00)00023-0

USAID. (2009). The Role of Local Governments in Promoting Decentralized Economic Governance in Indonesia. Retrieved from http://pdf.usaid.gov/pdf_docs/Pnadq131.pdf

\section{Appendix: The Methodology of Geweke Causality Analysis}

\section{Distribution of Statistics}

Under the null hypothesis that there is no unidirectional causality running from $\mathrm{Y}$ to $\mathrm{X}$ :

$$
\begin{aligned}
& \text { i.e. if } F_{Y \rightarrow X}=0 \text {, then } n \widehat{F}_{Y \rightarrow X} \sim \chi^{2}(k l p) \\
& \text { If } F_{X \rightarrow Y}=0 \text {, then } n \hat{F}_{X \rightarrow Y} \sim \chi^{2}(k l p) \\
& \text { If } F_{X \cdot Y}=0 \text {, then } n \hat{F}_{X \cdot Y} \sim \chi^{2}(k l)
\end{aligned}
$$


Since these tests are tests of nested hypotheses, $\hat{F}_{Y \rightarrow X}, \widehat{F}_{X \rightarrow Y}$, and $\hat{F}_{X \cdot Y}$ are asymptotically independent. The measure of linear feedback between $X$ and $Y, F_{X, Y}$, can be tested at once:

If $F_{X, Y}=0$.

$$
n \widehat{F}_{X, Y} \sim \chi^{2}(k l(2 p+1))
$$

\section{Confidence Interval}

The 95 percent confidence interval (CI) could be calculated approximately as follows:

For $\widehat{F}_{Y \rightarrow X}$,

$$
\left\{\left[\left(\widehat{F}_{Y \rightarrow X}-\frac{k l p-1}{3 n}\right)^{1 / 2}-\frac{1.96}{\sqrt{n}}\right]^{2}-\frac{2 k l p+1}{3 n},\left[\left(\widehat{F}_{Y \rightarrow X}-\frac{k l p-1}{3 n}\right)^{1 / 2}+\frac{1.96}{\sqrt{n}}\right]^{2}-\frac{2 k l p+1}{3 n}\right\}
$$

For $\widehat{F}_{X \rightarrow Y}$,

$$
\left\{\left[\left(\widehat{F}_{X \rightarrow Y}-\frac{k l p-1}{3 n}\right)^{1 / 2}-\frac{1.96}{\sqrt{n}}\right]^{2}-\frac{2 k l p+1}{3 n},\left[\left(\widehat{F}_{X \rightarrow Y}-\frac{k l p-1}{3 n}\right)^{1 / 2}+\frac{1.96}{\sqrt{n}}\right]^{2}-\frac{2 k l p+1}{3 n}\right\}
$$

For $\widehat{F}_{X \cdot Y}$,

$$
\left\{\left[\left(\hat{F}_{X \cdot Y}-\frac{k l-1}{3 n}\right)^{1 / 2}-\frac{1.96}{\sqrt{n}}\right]^{2}-\frac{2 k l+1}{3 n},\left[\left(\hat{F}_{X \cdot Y}-\frac{k l-1}{3 n}\right)^{1 / 2}+\frac{1.96}{\sqrt{n}}\right]^{2}-\frac{2 k l+1}{3 n}\right\}
$$

For $\widehat{F}_{X, Y}$,

$$
\left\{\left[\left(\widehat{F}_{X, Y}-\frac{k l(2 p+1)-1}{3 n}\right)^{\frac{1}{2}}-\frac{1.96}{\sqrt{n}}\right]^{2}-\frac{2 k l(2 p+1)+1}{3 n},\left[\left(\widehat{F}_{X \cdot Y}-\frac{k l(2 p+1)-1}{3 n}\right)^{\frac{1}{2}}+\frac{1.96}{\sqrt{n}}\right]^{2}-\frac{2 k l(2 p+1)+1}{3 n}\right\}
$$

\section{Copyrights}

Copyright for this article is retained by the author(s), with first publication rights granted to the journal.

This is an open-access article distributed under the terms and conditions of the Creative Commons Attribution license which permits unrestricted use, distribution, and reproduction in any medium, provided the original work is properly cited. 